
MENGGUNAKAN MIKROKONTROLER ARDUINO VIA BLUETOOTH

\author{
${ }^{1}$ Pratiwi Retno Wigati \\ ${ }^{1}$ Program Studi Teknik Informatika Universitas Yudharta \\ 1e-mail : pratiwi@gmail.com
}

\begin{abstract}
As technological developments are more advanced and open with the current globalization as now, it is expected that advanced technology can provide convenience in all areas, such as measurement and temperature monitoring for example. Therefore, it takes a tool that serves to convert the amount of heat into a quantity of electricity that can easily be analyzed amount of temperature sensors. This research begins with the human body temperature that will be detected by arduino microcontroller temperature sensor. The receiver interacts the detection device using the LM35 temperature sensor. The result of the temperature change will be read and processed on the arduino microcontroller.In testing the accuracy of body temperature value, temperature measurement is done by putting the body temperature sensor LM35di body part that is neck, mouth, right armpit, armpit left, chest and back.That The measurement of the temperature sensor that is LM35 compared to the thermometer, is able to work well. The percentage error rate of the temperature sensor is 0\%. According to the LM35 sensor testing compared to a thermometer, having a temperature range difference is zero comma, so the results of the measurement are still in tolerance.
\end{abstract}

Keywords: Temperature Sensor, Arduino, Bluetooth

\title{
I PENDAHULUAN
}

Seiring dengan perkembangan zaman dan teknologi kebutuhan informasi yang cepat, sangat dibutuhkan dalam berbagai bidang. Salah satu kebutuhan informasi tersebut adalah informasi mengenai suhu. Dalam pengukuran suhu, suhu tergantung dari faktor eksternal dan faktor internal. Maka dari itu, dibutuhkan alat yang berfungsi mengubah besaran panas menjadi besaran listrik yang dapat dengan mudah dianalisis besarannya yaitu sensor suhu.

Sensor suhu melakukan pengukuran terhadap jumlah energi panas/tinggi yang dihasilkan oleh suatu objek. Sehingga memungkinkan untuk mengetahui atau mendeteksi gejala perubahan-perubahan suhu tersebut. Sensor suhu yang digunakan adalah sensor suhu IC-LM35 dan perangkat displai hasil pengukuran yang digunakan adalah smartphone dengan OS android. Sensor ini adalah pendekteksi perubahan suhu, kemudian hasil perubahan suhu akan dibaca dan diproses pada mikrocontroller, setelah data terproses selanjutnya data akan dikirimkan keperangkat android melalui koneksi bluetooth. Perkembangan alat deteksi yang digunakan adalah sensor suhu IC-LM35 dengan program Arduino.

Arduino dapat dikatakan sebuah platform dari physical computing yang bersifat open source. Arduino tidak hanya sekedar alat perkembangan, kombinasi dari hardware, bahasa pemrograman dan integrated Development Environment (IDE) yang canggih. IDE adalah sebuah software yang berperan untuk menulis program, meng-compile, menjadi kode biner dan meng-upload ke dalam memori microcontroller. Microcontroller adalah sebuah sistem mikroprosesor dimana didalamnya sudah terdapat CPU, Read Only Memory (ROM), Random Access Memory (RAM), Input-Output, Timer, Interrupt, Clock dan peralatan 
internal lainnya yang sudah saling terhubung dan terorganisasi dengan baik dalam satu chip yang siap dipakai.

Program arduino untuk sensor suhu LM35 memungkinkan untuk menuliskan barisan program yang dapat membaca data senspr LM35 yang itu mengubah data analog sensor menjadi data digital pada arduino. Arduino lebih kompatibel dan fleksibel, sehingga program ketika menyentuh sensor suhu lebih baik dan itu bisa merubah kode scriptnya tanpa membongkar atau mensolder rangkaian.

\section{TINJAUAN PUSTAKA}

\subsubsection{Arduino}

Arduino adalah platform pembuatan prototipe elektronik yang bersifat open-source hardware yang berdasarkan pada perangkat keras dan perangkat lunak yang fleksibel dan mudah digunakan. Arduino ditujukan bagi para seniman, desainer, dan siapapun yang tertarik dalam menciptakan objek atau lingkungan yang interaktif.

Arduino pada awalnya dikembangkan di Ivrea, Italia. Nama Arduino adalah sebuah nama maskulin yang berarti teman yang kuat. Platform arduino terdiri dari arduino board, shield, bahasa pemrograman arduino, dan arduino development environment. Arduino board biasanya memiliki sebuah chip dasar mikrokontroler Atmel AVR ATmega8 berikut turunannya.

Arduino tidak hanya sekedar sebuah alat pengembangan, tetapi ia adalah kombinasi darihardware, bahasa pemrograman dan Integrated Development Environment (IDE) yang canggih. IDE adalah sebuah software yang sangat berperan untuk menulis program, meng-compile menjadi kode biner dan meng-upload ke dalam memory microcontroller. Ada banyak projek dan alat-alat dikembangkan oleh akademisi dan profesional dengan menggunakan Arduino, selain itu juga ada banyak modul-modul pendukung (sensor, tampilan, penggerak dan sebagainya) yang dibuat oleh pihak lain untuk bisa disambungkan dengan Arduino.

Arduino berevolusi menjadi sebuah platform karena ia menjadi pilihan dan acuan bagi banyak praktisi. Software lebih mudah diubah dibandingkan hardware, dengan beberapa penekanan tombol kita dapat merubah logika alat secara radikal dan mencoba versi ke-dua, ke-tiga dan seterusnya dengan cepat tanpa harus mengubah pengkabelan dari rangkaian. Salah satu yang membuat Arduino memikat hati banyak orang adalah karena sifatnya yang open source, baik untuk hardware maupun software-nya.

Arduino Uno adalah arduino board yang menggunakan mikrokontroler ATmega328. Arduino Uno memiliki 14 pin digital (6 pin dapat digunakan sebagai output PWM), 6 input analog, sebuah $16 \mathrm{MHz}$ osilator kristal, sebuah koneksi USB, sebuah konektor sumber tegangan, sebuah header ICSP, dan sebuah tombol reset. Arduino Uno memiliki area cakupan yang luas untuk segala hal yang dibutuhkan untuk mendukung sebuah aplikasi yang berbasiskan mikrokontroler. Hanya dengan menghubungkannya ke sebuah komputer melalui USB atau memberikan tegangan DC dari baterai atau adaptor AC ke DC sudah dapat membuat aplikasinya bekerja. Arduino Uno menggunakan ATmega16U2 yang diprogram sebagai USB-toserial converter untuk komunikasi serial ke komputer melalui port USB.

\subsubsection{Sensor LM35}

Sensor merupakan jenis tranduser yang digunakan untuk mengubah besaran mekanis, magnetis, panas, sinar, dan kimia menjadi tegangan dan arus listrik. Sensor sering digunakan untuk pendeteksian pada saat melakukan pengukuran atau pengendalian. Beberapa jenis sensor yang banyak digunakan dalam rangkaian elektronik antara lain sensor cahaya(LDR), sensor suhu(LM35), dan sensor kelembaban uadara(DHT11).

Dalam melakukan analisa ini digunakan sensor tipe LM35 yang digunakan sebagai alat sensor suhu didalam rangkaian dengan menggunakan supplay tegangan sebesar 0-5V dari Arduino yang merupakan board elektronik atau papan rangkaian elektronik open source yang di dalamnya terdapat komponen utama yaitu sebuah chip mikrokontroler dengan jenis AVR dari perusahaan Atmel.Mikrokontroler itu sendiri adalah chip atau IC (integrated circuit) yang bisa diprogram menggunakan komputer. Tujuan menanamkan program 
pada mikrokontroler adalah agar rangkaian elektronik dapat membaca input, memproses input tersebut dan kemudian menghasilkan output sesuai yang diinginkan.

Mikrokontroler juga dipakai untuk keperluan mengendalikan robot. Baik robot mainan, maupun robot industri. Untuk mendeteki keadaan alam sekitar berupa data hasil analog input yang dibaca oleh sensor maka dibawah ini terdapat beberapa dasar teori yang menjadi acuan untuk mengenal cara kerja sensor yang digunakan dalam penelitian ini adalah sebagai berikut :

\subsubsection{Sensor suhu / Temperature (LM35)}

Karena komponen utama Arduino adalah mikrokontroler, maka Arduino pun dapat diprogram menggunakan komputer sesuai kebutuhan kita. untuk dapat mengukur suhu ruangan dibutuhkan satu komponen saja yaitu LM35.

Selain modul mikrokontroler Arduino.LM35 adalah sensor suhu dari National Semiconductor yang mempunyai akurasi tinggi. Outputnya berupa tegangan analog dan memiliki jangkauan pengukuran $-55^{\circ} \mathrm{C}$ hingga $+150^{\circ} \mathrm{C}$ dengan akurasi $\pm 0.5^{\circ} \mathrm{C}$. Tegangan output adalah $10 \mathrm{mV} /{ }^{\circ} \mathrm{C}$.

Output dapat langsung dihubungkan port mikrokontroler yang memiliki ADC atau dengan Arduino,

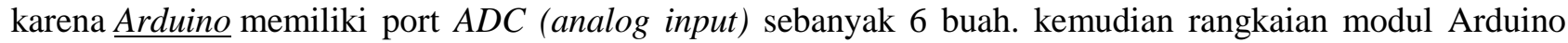
dengan sensor suhu seperti gambar di bawah ini :

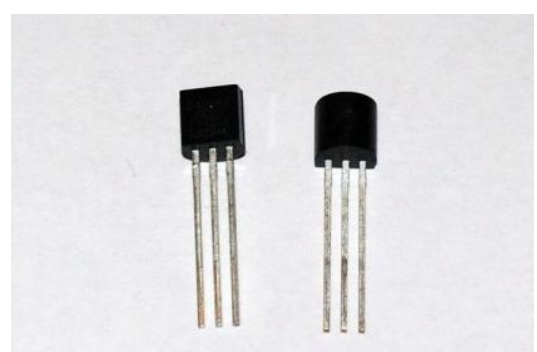

Gambar 1 Sensor suhu/Temperature (LM35)

\subsubsection{Android}

Android adalah software besutan Google yang mencakup sistem operasi atau OS, middleware, dan aplikasi kunci yang berbasis Linux pada suatu gadget seperti telephone cellular, smartphone dan komputer tablet. Android persis seperti symbian yang dipergunakan oleh Nokia dan BlackBerry OS. Jelasnya seperti microsoft windows yang sangat dikenal baik oleh para pengguna komputer dan laptop. Jika dianalogikan, Android adalah windows-nya sedangkan smartphone atau komputer tablet adalah unit komputernya.

Android menyediakan platform terbuka (open souces) bagi para pengembang untuk menciptakan aplikasi mereka sendiri untuk digunakan oleh berbagai macam piranti bergerak. Awalnya, Google Inc. membeli Android Inc., pendatang baru yang membuat piranti lunak untuk ponsel. Kemudian Google Inc mengembangkannya dengan cara membentuk Open Handset Alliance (OHD), konsorsium dari 34 perusahaan peranti keras, peranti lunak, dan telekomunikasi, termasuk Google, HTC, Intel, LG, Motorola, Qualcomm, T-Mobile, Samsung dan Nvidia.

Di dunia ini terdapat dua jenis distributor sistem operasi Android. Pertama yang mendapat dukungan penuh dari Google atau Google Mail Services (GMS) dan yang kedua adalah yang benar-benar bebas distribusinya tanpa dukungan langsung Google atau dikenal sebagai Open Handset Distribution. Keputusan Google Inc. mengembangkan Android dengan cara membentuk Open Handset Distribution dinilai sangat tepat karena melalui hal tersebut saat ini Android telah berhasil menjadi salah satu sistem operasi paling populer. Saking populernya Android pun dapat mengalahkan sistem operasi lain seperti iOS, Windows Phone, dan Blackberry.

Dengan sistem distribusi open sources yang digunakan Android, memungkinkan para pengembang untuk menciptakan berbagai macam aplikasi menarik yang dapat dinikmati oleh para penggunanya, seperti 
game, chatting dan lain-lain, hal ini pulalah yang membuat smartphone berbasis Android ini lebih murah dibanding gadget sejenisnya.

\section{METODE PENELITIAN}

\subsection{Analisis Kebutuhan Perangkat Lunak}

\subsubsection{Kebutuhan Perangkat Lunak}

Perangkat lunak yang dibutuhkan untuk membangun aplikasi ini adalah :

a. Sistem operasi Windows 7 ultimate 32 bit

b. Arduino IDE 1.8.1

c. Pemrograman android app inventor

\subsubsection{Kebutuhan Perangkat Keras}

Perangkat keras yang dibutuhkan untuk membangun aplikasi ini adalah :

1. Komputer/laptop

2. Smartphone android 2.0

3. Arduino

4. Modul Bluetooth HC.05

5. Sensor LM35

6. Kabel Jumper

\subsection{Perancangan Global Sistem}

Adapun perancangan global sistem pada penelitian ini sebagai berikut

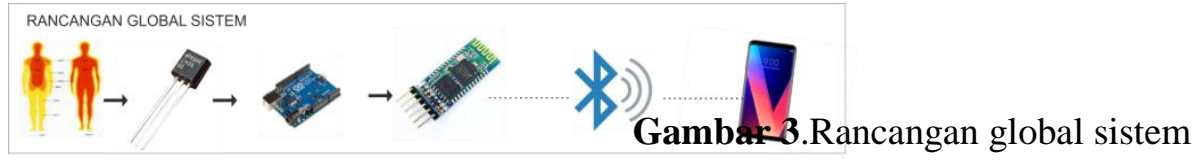

Penjelasan :

1. Penelitian ini diawali dengan adanya suhu tubuh pada manusia yang akan di deteksi oleh sensor suhu mikrokontroller arduino

2. Selanjutnya, suhu akan di deteksi oleh sensor suhu LM35.

3. Input dari sensor suhu LM35 akan diteruskan ke arduino untuk di proses ke bluetooth.

4. Bluetooth HC05 akan mengirimkan nilai hasil sensor untuk dikirimkan ke smartphone.

5. Smartphone android menerima nilai hasil sensor dan menampilkannya dalam satuan derajad celcius.

6. Selanjutnya android menyimpan nilai suhu dan merekamnya secara terus menerus

\subsection{Diagram Block Sistem}

Adapun diagram block sistem pada penelitian ini sebagai berikut

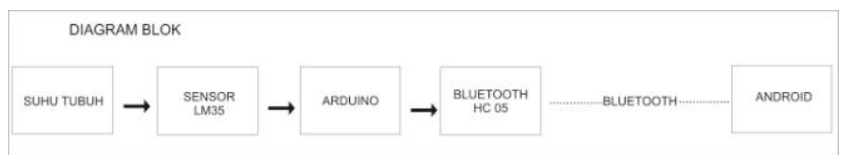

Gambar 4 Diagram Block Sistem 


\subsection{Flow chart}

Adapun flowchart pada penelitian iniadalah sebagai berikut

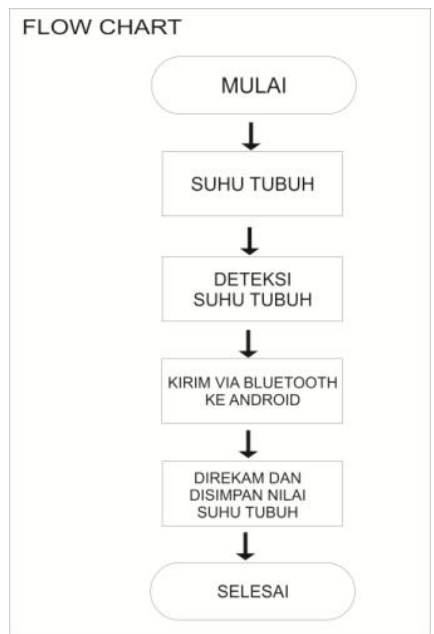

Gambar 5 Flow Chart Sistem

\subsection{Rangkaian elektronika}

Adapun rangkaian elektronika pada penelitian ini adalah sebagai berikut

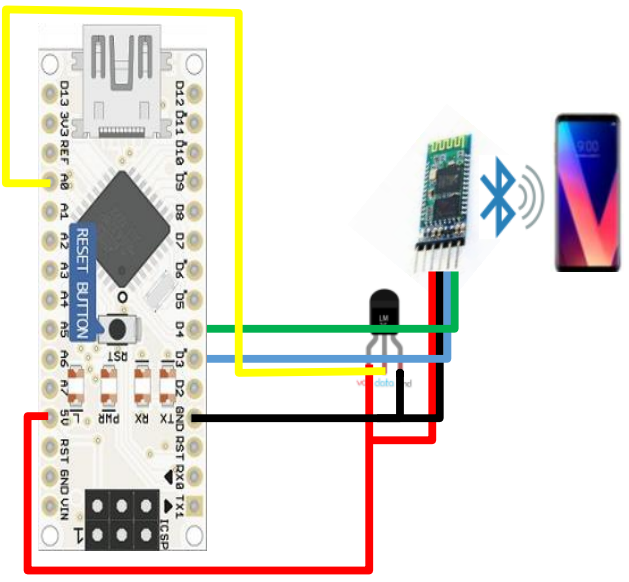

Gambar 6 Rangkaian Elektronika

\subsection{Use Case}

Use case Diagram merupakan konstruksi untuk mendeskripsikan hubungan - hubungan yang terjadi antarauser dengan aktivitas yang terdapat pada aplikasi. Dari hasil analisis aplikasi yang ada maka usecase 
diagram untuk aplikasi monitoring suhu tubuh menggunakan arduino dengan koneksi bluetooth android dapat di lihat pada gambar berikut:

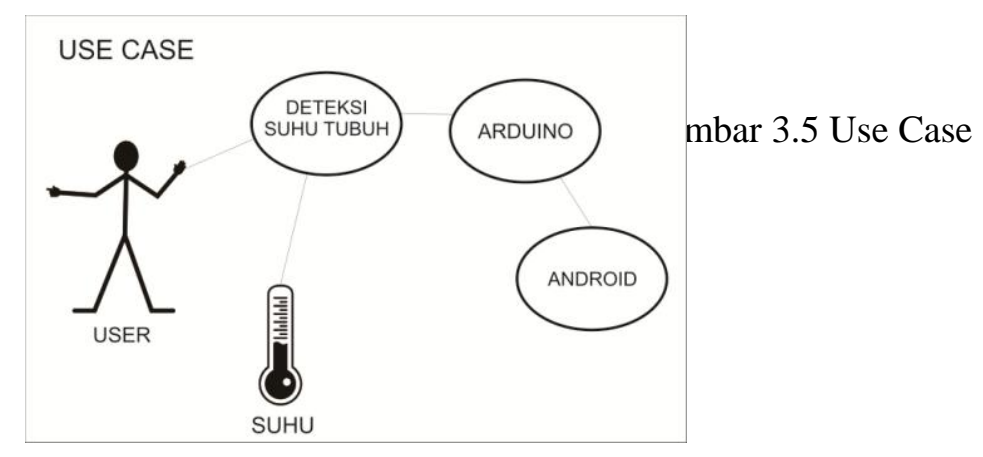

Gambar 7 Use Case

Gambar diatas berikut ini menjelaskan bagaimana pengguna menggunakan sistem. Pengguna yang terdapat di dalam sistem teknik deteksi suhu tubuh dengan menggunakan proses arduino ini adalah penerima. Pada bagian penerima dilakukan interaksi alat deteksidengan menggunakan sensor suhu LM35. Hasil perubahan suhu akan dibaca dan diproses pada mikrokontroler arduino. Data yang terproses, selanjutnya data akan dikirimkan ke perangkat android melalui koneksi bluetooth.

\subsection{Pengujian system}

Adapun pengujian yang akan dilakukan pada penelitian ini sebagai berikut :

\subsubsection{Pengujian akurasi nilai suhu tubuh}

Pada pengujian akurasi nilai suhu tubuh, pengukuran suhu dilakukan dengan meletakkan sensor suhu tubuh LM35di bagian tubuh yaitu leher, mulut, ketiak kanan, ketiak kiri, dada dan punggung. Kemudian data hasil uji alat pengukur suhu tubuh di deteksi tanpa kontak fisik ke Arduino. Data nilai suhu tubuh terekam pada android melalui bluetooth.

\subsubsection{Pengujian jarak sensor suhu terhadap smartphone android}

Adapun yang dimaksud pengujian ini adalah mengukur jarak panjang smartphone android dengan arduino. Jarak yang digunakan yaitu $10 \mathrm{~cm}, 30 \mathrm{~cm}, 50 \mathrm{~cm}, 70 \mathrm{~cm}, 90 \mathrm{~cm}, 110 \mathrm{~cm}, 130 \mathrm{~cm} \ldots . .500 \mathrm{~cm}$

\section{HASIL DAN PEMBAHASAN}

Bab ini akan membahas tentang hasil pengujian software yang telah di buat pada arduino terhadap modul bluetooth HC.05. Tujuan dari pengujian ini adalah mengetahui apakah software yang telah dibuat sesuai dengan spesifikasi perancangan. Selain juga untuk mengetahui detail software serta permasalahan yang ada agar dapat dilakukan perbaikan dan pengembangan lebih lanjut.

\subsection{Perangkat Keras ( Hardware )}

Perangkat keras ( Hardware) yang digunakan pada percobaan ini adalah sebagai berikut :

1. Komputer/laptop

2. Smartphone android 2.0

3. Arduino

4. Modul Bluetooth HC.05

5. Kabel USB 


\subsection{Perangkat Lunak ( Software )}

Sedangkan untuk spesifikasi perangkat lunak yang digunakan adalah sebagai berikut :

1. Sistem Operasi Windows 7 ultimate 32 bit

2. Arduino IDE 1.8.1

3. Skrip Modul Bluetooth HC.05

\subsection{Sistem pembuatan/development}

\subsubsection{Install Software IDE 1.8.5 Arduino}

Setelah berhasil mengunduh file installer, double click file tersebut untuk segera memulai proses instalasi.

1. Setelah file installer dijalankan, akan muncul jendela 'Licence Agreement'. Klik tombol 'I Agree'

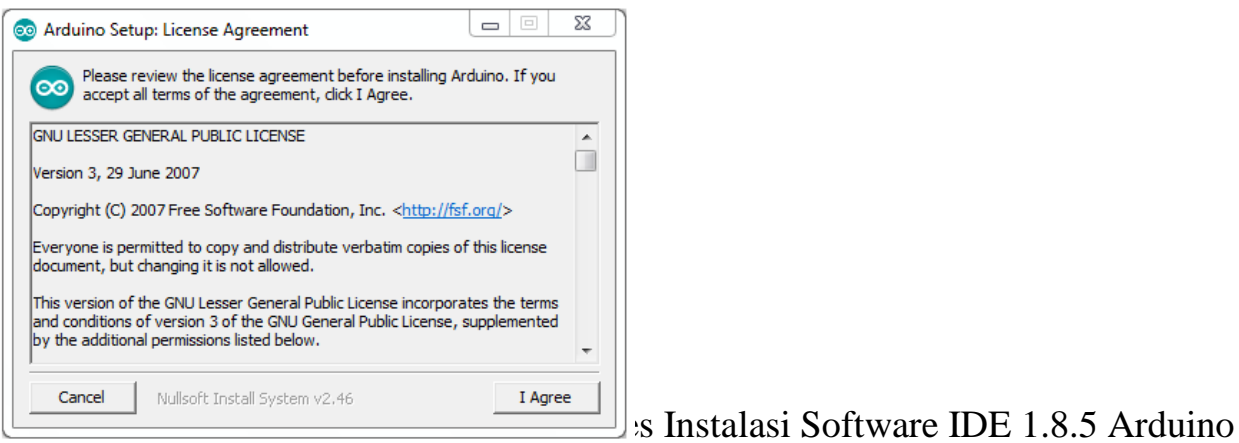

2. Berikutnya masukkan folder instalasi arduino. Biarkan default di C:\Program Files\Arduino.

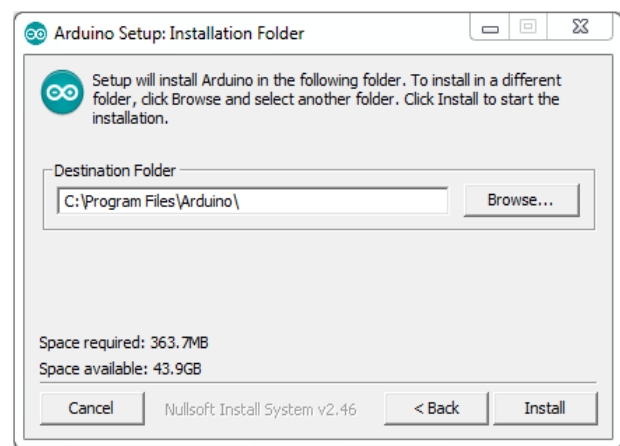

Gambar 9 Installation Folder

3. Setelah itu muncul jendela 'Setup Installation Options' centang semua pada opsinya

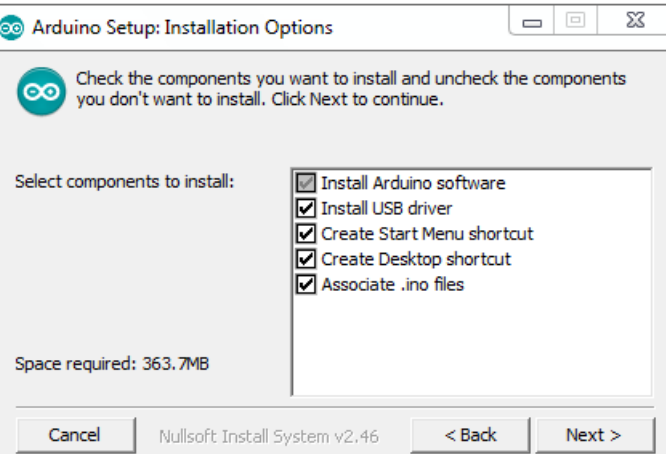




\section{Gambar 11 Setup Installation Folder}

4. Selanjutnya proses instalasi akan dimulai

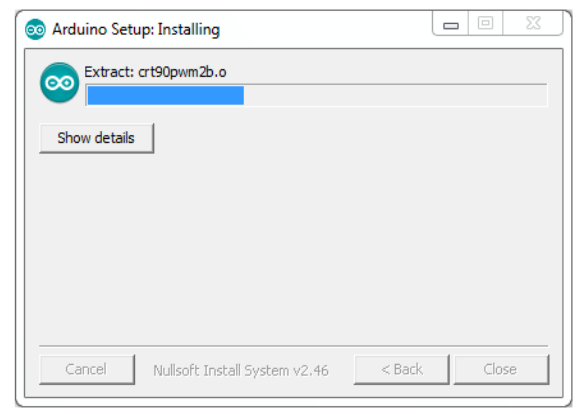

\section{Gambar 12 Installing Proses}

5. Di tengah proses instalasi, jika komputer belum terinstal driver USB, maka akan muncul jendela 'Security Warning'.Pilih tombol 'install'

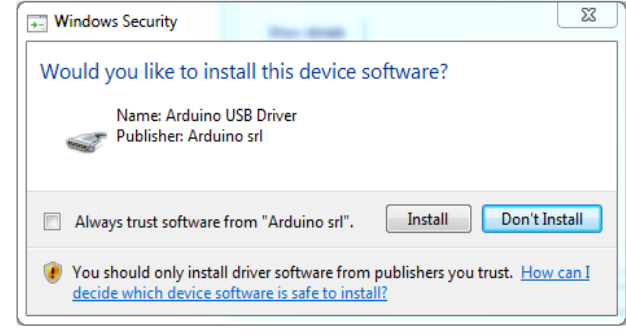

Gambar 13Jendela Windows Security

6. Tunggu sampai proses instalasi 'Completed'

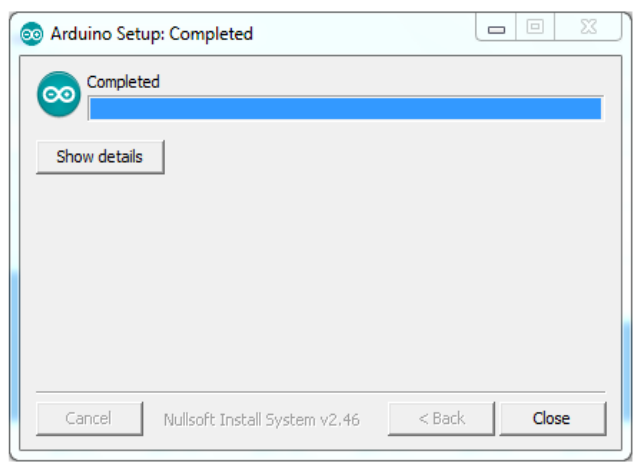




\section{Gambar 14 Installing Complete}

7. Pada tahap ini software IDE Arduino sudah terinstal. Cek di start Menu Windows atau dekstop akan muncul ikon Arduino.Jalankan aplikasinya dan akan muncul splash screen seperti gambar dibawah ini :

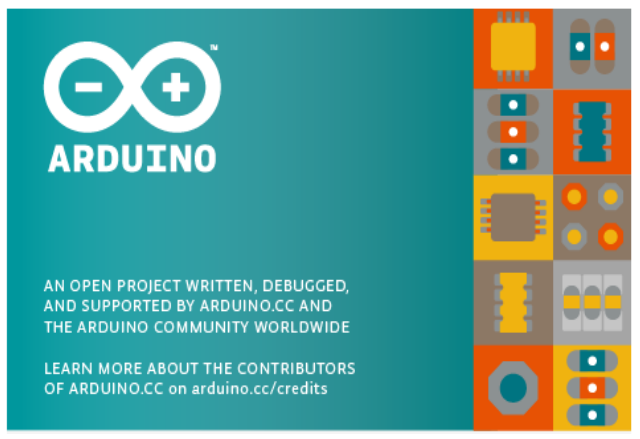

Gambar 15 Arduino IDE

8. Beberapa detik kemudian, jendela IDE Arduino akan muncul

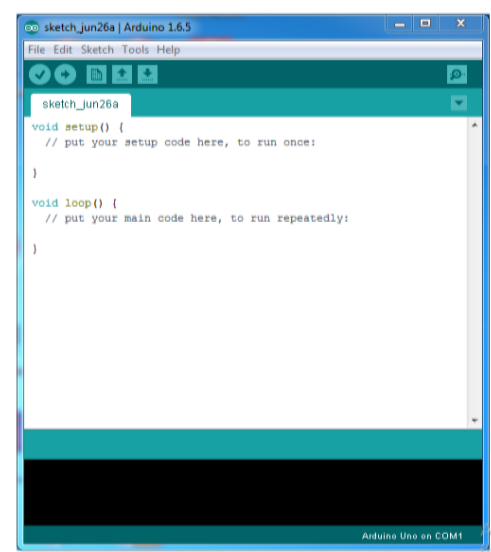

Gambar 16 Jendela Arduino IDE

9. Konfiguras Arduino dengan software

1. Hubungkan port USB pada Arduino dengan Laptop

2. Klik 2 kali pada aplikasi Arduino

3. Buka contoh Blink : File $>$ Example $>1$. Basic $>$ Blink. 


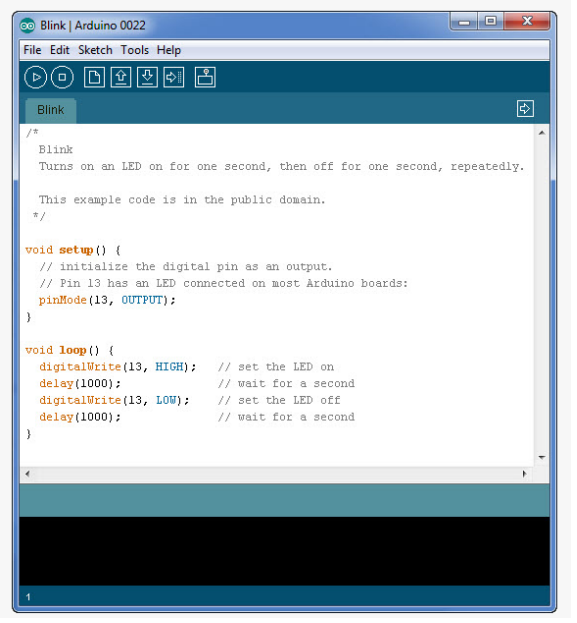

Gambar 17 Konfigurasi Arduino dengan software

4. Pilih Board pada menu Tools > Board yang sesuai dengan board Arduino yang dipakai.

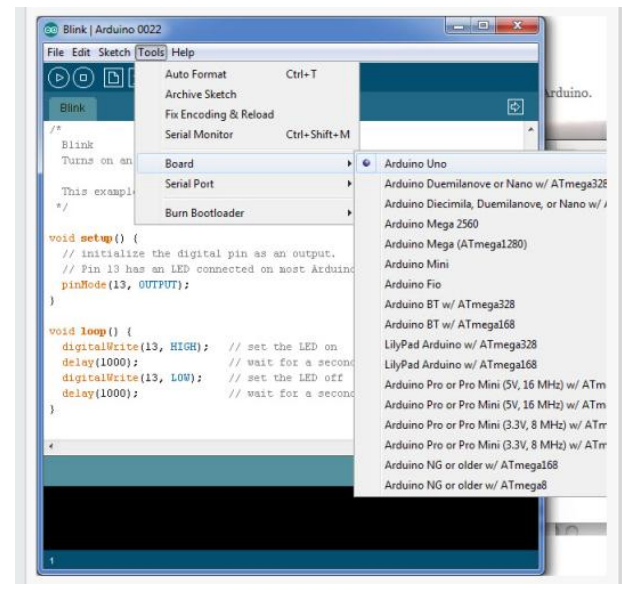

Gambar 18 Board Arduino IDE

5. Pilih serial port digunakan oleh board Arduino pada menu Tools > Serial Port. Pilih COM3 atau yang lebih tinggi (COM1 dan COM2 sudah direservasi untuk serial port hardware). Untuk mencari tahu, dapat melepaskan koneksi ke board Arduino dan buka kembali menu tadi; pilihan yang menghilang harusnya adalah board Arduino. Koneksikan kembali board-nya dan pilih serial port yang sesuai.

6. Upload program

Klik tombol "Upload" pada software. Tunggu beberapa saat lihat led TX dan RX pada board berkelap-kelip. Bila upload berhasil akan ada pesan "Done uploading." yang muncul pada status bar.

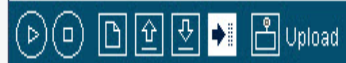

Gambar 19 Tampilan Upload Software 
Beberapa saat setelah upload selesai, anda dapat melihat pin 13 (L) LED pada board mulai berkelap-kelip (warna oranye). Jika benar, maka berhasil menjalankan Arduino dan program-nya dengan sukses.

\subsection{Aplikasi android}

Adapun aplikasi android yang dibuat pada penelitian ini menggunakan app inventor. Berikut ini adalah layout tampilan aplikasinya:

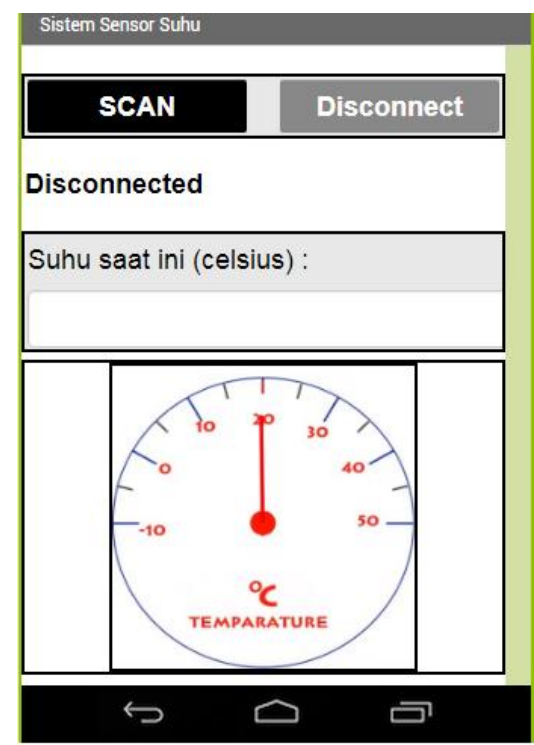

Gambar 20 Layout Aplikasi Android

Penjelasan gambar 4.14 :

- SCAN, digunakan apabila Bluetooth belum terdeteksi

- Connected, jika Bluetooth handphone telah tersambung ke modul hardware dan terhubung ke aplikasi sensor suhu

- Disconnect, apabila koneksi Bluetooth tidak terhubung atau belum dinyalakan.

- Suhu Saat Ini, proses akhir jika Bluetooth telah tersambung pada aplikasi sensor suhu dan data suhu terlihat. 
Adapun Skrip app inventor yang digunakan adalah sebagai berikut :

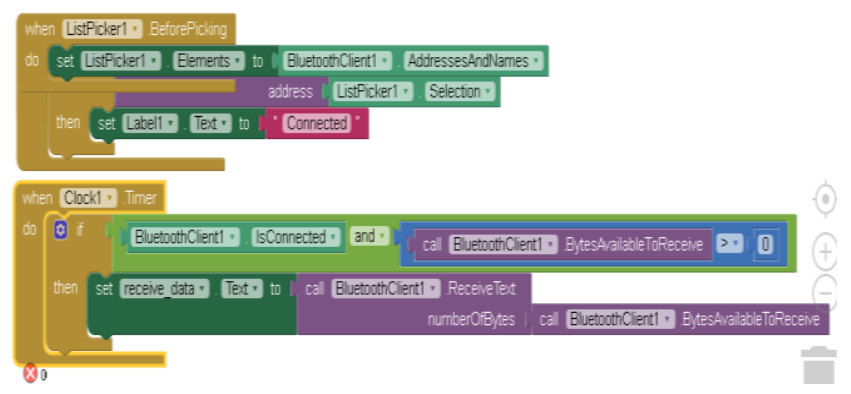

Gambar 21Skrip App inventor

\subsection{Pengujian Alat}

Adapun pengujian yang akan dilakukan pada penelitian ini sebagai berikut :

\subsubsection{Pengujian akurasi nilai suhu tubuh}

Pada pengujian akurasi nilai suhu tubuh, pengukuran suhu dilakukan dengan meletakkan sensor suhu tubuh LM35 di bagian tubuh yaitu leher, mulut, ketiak kanan, ketiak kiri, dada dan punggung. Kemudian data hasil uji alat pengukur suhu tubuh di deteksi tanpa kontak fisik ke Arduino. Data nilai suhu tubuh terekam pada android melalui Bluetoot

Tabel 1 Data Nilai Suhu Tubuh

\begin{tabular}{|c|c|c|}
\hline No & Bagian Tubuh & Suhu(celcius) \\
\hline 1 & Leher & 35 \\
\hline 2 & Mulut & 36 \\
\hline 3 & Ketiak kanan & 37 \\
\hline 4 & Ketiak kiri & 37 \\
\hline 5 & Dada & 33 \\
\hline 6 & Punggung & 35 \\
\hline
\end{tabular}

\subsubsection{Pengujian jarak sensor suhu terhadap smartphone android}

Adapun yang dimaksud pengujian ini adalah mengukur jarak panjang smartphone android dengan arduino.

Tabel 2 Jarak Sensor Suhu terhadap Smartphone Android

\begin{tabular}{|c|c|l|}
\hline No & Jarak $(\mathrm{cm})$ & $\begin{array}{c}\text { Koneksi ke } \\
\text { Android }\end{array}$ \\
\hline 1 & 10 & berhasil \\
\hline 2 & 20 & berhasil \\
\hline
\end{tabular}




\begin{tabular}{|c|c|l|}
\hline 3 & 30 & berhasil \\
\hline 4 & 40 & berhasil \\
\hline 5 & 50 & berhasil \\
\hline 6 & 60 & berhasil \\
\hline 7 & 70 & berhasil \\
\hline 8 & 80 & berhasil \\
\hline 9 & 90 & berhasil \\
\hline 10 & 100 & berhasil \\
\hline 11 & 200 & berhasil \\
\hline 12 & 300 & berhasil \\
\hline 13 & 400 & berhasil \\
\hline 14 & 500 & berhasil \\
\hline 15 & 800 & Tidak berhasil \\
\hline
\end{tabular}

\subsubsection{Pengujian akurasi sensor suhu dengan} termometer

Adapun yang dimaksud pengujian ini adalah membandingkan keakurasian nilai sensor suhu dengan termometer.

Tabel 3 Akurasi sensor suhu dengan termometer

\begin{tabular}{|c|c|c|c|}
\hline No & $\begin{array}{c}\text { Bagian } \\
\text { Tubuh }\end{array}$ & $\begin{array}{c}\text { Sensor } \\
\text { suhu } \\
\text { (celcius) }\end{array}$ & $\begin{array}{c}\text { Termometer } \\
\text { (celcius) }\end{array}$ \\
\hline 1 & Leher & 35 & 35,6 \\
\hline 2 & Mulut & 36 & 36,4 \\
\hline 3 & $\begin{array}{c}\text { Ketiak } \\
\text { kanan }\end{array}$ & 37 & 37 \\
\hline 4 & Ketiak kiri & 37 & 37 \\
\hline 5 & Dada & 33 & 32,5 \\
\hline 6 & Punggung & 35 & 35,5 \\
\hline
\end{tabular}

\section{KESIMPULAN DAN SARAN}

\subsection{Kesimpulan}

Berdasarkan Implementasi dan hasil pengujian dapat diambil kesimpulan sebagai berikut:

1. Smartphone bisa terhubung dan memberi perintah pada Modul Bluetooth melalui konektivitas Bluetooth dan menghasilkan data suhu tubuh manusia

2. Penelitian ini merupakan hasil pengembangan dari penelitian sebelumnya dimana menggunakan media jaket dan handphone untuk mengontrol suhu tubuh. Penelitian ini dilakukan dengan menggunakan sensor sebagai pendeteksi perubahan suhu tubuh yang kemudian hasil perubahan suhu akan dibaca dan diproses pada mikrokontroler ATMega8a-pu. Data yang terproses, selanjutnya data akan dikirimkan ke perangkat android melalui koneksi bluetooth.

3. Modul Bluetooth HC.05 dapat digunakan untuk mengidentifikasi sensor Bluetooth dengan baik dan dalam pembuatan aplikasi sensor suhu

\subsection{Saran}

Adapun saran dari penyusun skripsi untuk dapat melakukan pengembangan selanjutnya adalah :

1. Sistem aplikasi sensor suhu pada penelitian ini membahas koneksi Bluetooth yang terhubung ke module bluetooth dengan mempertimbangkan jarak ukur, apabila handphone berada pada jarak tertentu, dalam hal ini jarak 8 meter koneksi terputus.Untuk selanjutnya dapat dikembangkan.

2. Sistem aplikasi sensor suhu pada penelitian ini dalam penyimpanan data hanya terbatas pada suhu terakhir yang terdeteksi. Untuk penelitian selanjutnya dapat dikembangkan dengan memberikan rekam data tersimpan pada smartphone, sehingga pengecekan suhu tubuh dapat terkontrol dengan baik. 


\section{DAFTAR PUSTAKA}

[1]Rajasa , Moh Fajar., Ya'umar, Suyanto. Rancang Bangun Prototipe Monitoring Suhu Tubuh Manusia Berbasis O.S Android Menggunakan Koneksi Bluetooth.Jurnal Teknik Promits.Vol 2 No. 1, 2013

[2]Susanto, Heri .,Pramana, Rozzef., Muhajidin Muhammad.Perancangan Sisten

Telemetri Wireless Untuk Mengukur Suhu Dan Kelembapan Berbasis Arduino Uno R3 Atmega328p Dan Xbee Pro, 2013

[3]Prathusha, M., Kalaiselvi, M.C., Sudhaa, S.Jaya.,Velthai, R.Solar Driven Aurdino Based Automatic Irrigation Using Gsm, 2016

[4]Ferdoush,Sheikh.,Li,Xinrong.Wireless Sensor Network System Design Using Raspberry Pi And Arduino For Environmental Monitoring Applications. 2014

[5]Prihatmoko,Dias.Perancangan Dan Implementasi Pengontrol Suhu Ruangan Berbasis Mikrokontroler Arduino Uno.Jurnal Simetris, Vol 7 No.1,1 April 2016 